\title{
The Influence of Low Serum Ferritin on Cardiac Autonomic Regulation in Libyan Patients
}

\author{
Hanan G. K. Altalhi $^{1^{*}}$, Asgad A. Abdalgbar ${ }^{1,2}$ \\ ${ }^{l}$ Department of Internal Medicine, Faculty of Medicine, University of Omar El mukhtar, Albayda, Libya \\ ${ }^{2}$ Department of Physiology, Faculty of Medicine, University of Omar El mukhtar, Albayda, Libya
}

*Corresponding Author: Hanan G.K. Altalhi, Department of Internal Medicine, Faculty of Medicine, University of Omar El maukhtar University, Albayda, Libya.

\begin{abstract}
Autonomic nervous system activity is impaired in anemic patients with various etiology such as vitamin B12 deficiency, thalassemia major and sickle cell trait however there are insufficient data about autonomic function in patient with iron deficiency anemia in general population study.
\end{abstract}

Aim: In present study we aimed to investigate the relationship between serum ferritin level and heart rate variability $(H R V)$.

Patients and Methods: This is case control study of 20 patients with iron deficiency anemia (case subject) and 20 healthy subjects.

ECG record was used for studying $H R V$, we used serum level of iron, ferritin, iron binding capacity, $C$ reactive protein, vitamin $B 12$ and folate to exclude other causes of anemia.

Result: Age, gender, vitamin B12, folate and serum electrolyte were not different between the groups, HRV value were lower in patients with iron deficiency anemia compared to control group.

Heart rate of study group (116 \pm 19$)$ was significantly greater than control group $(78 \pm 19, P<0.05), H b, H C T$, $M C V$ and ferritin value were significantly lower in study group than in control group $(8.5 \pm 2.3$ vs $13.2 \pm 0.4$, $P<0.05 \quad 30.1 \pm 1.1$ vs $41.2 \pm 1.1, \quad P<0.05, \quad 67.3 \pm 2.1$ vs $84.5 \pm 2.4, \quad P<0.05, \quad 5.1 \pm 0.4$ vs $97 \pm 6.5, \quad P<0.05$ respectively).

SDNN, SDANN and RMSSD were significantly lower in study group than in control group $(116 \pm 38$ vs $139 \pm 41, P<0.0596 \pm 32$ vs $122 \pm 38, P<0.0523 \pm 12$ vs $29 \pm 11, P=0.26$ respectively).

Conclusion: Lower serum ferritin is associated with lower HRV putting anemic patient at high cardiac risk.

Keywords: Heart rate variability, autonomic function, iron deficiency anemia, Electrocardiographic.

\section{INTRODUCTION}

Heart rate variability (HRV) asses the difference of the period between consecutive heart beats, which vary under autonomic control. Decreased HRV has been recognized as strong indicator of risk related to adverse events in healthy individual as well as diseased patient, reflecting the vital role of the autonomic nervous system in maintain health (Vanderlei LC, et al 2009; Task for the European society of cardiology, the north American society of pacing and electrophysiology 1996) (Gandhi RA, et al 2010; Schroeder E, et al 2003).

HRV can be measured by the time domain method (task force of the European society of pacing electrophysiology 1996).

Cardiac autonomic function have been demonstrated to be impaired in various disorder including diabetes mellitus (Gandhi RA, et al 2010, hypertension (Shroeder E et al 2003), ischemic heart disease (Gehi A, et al 2005; Liew $R, 2010$ ), the degree of fluctuation of the beat to beat difference in cardiac rhythm is an indirect method for cardiac autonomic function determination it has extensively used for that purpose as reliable and non invasive.

\section{Method}

This is case control study of 40 patients, 20 patients with iron deficiency anemia (case subject) and 20 healthy subject (control subject), data were collected through interview cases and controls, physical examination done by the study physician. Patients were included if they were between 20 and 40 year.

Subjects with past medical history suggestive of smoking, diabetes, hypertension, heart diseases, 
vitamin B12 or folate deficiency, sickle cell disease, thalasemia were excluded from the study.

The diagnosis of anemia was made according to complete blood count, serum ferritin, vitamin B12 and folate levels.

Apart from lower serum ferritin level $<100 \mu \mathrm{g} / \mathrm{L}$ (Anker, S et al 2009), whole hemoglobin value below $11.7 \mathrm{~g} / \mathrm{dl}$ for female and $13 \mathrm{~g} / \mathrm{dl}$ for males were recorded as satisfactory criteria for the diagnosis of iron deficiency anemia.We used serum iron, serum iron binding capacity $\mathrm{C}$ reactive protein for excluding the patient with other cause of anemia.

\subsection{Heart Rate Variability}

ECG recorder was used for studying HRV. Patients were advised to lie down (in supine position) and breath comfortably ensuring clean ECG signals, the ECG recording was initiated. Heart rhythm scanner, manually finish the trial session once it is time expire (5 minutes). Any medication was stopped at least one week prior to ECG examination.

Time domain indices for HRV from ECG were calculated by cardiologist.

The time domain HRV parameters that measured in our study, were the standard deviation of all normal sinus R-R interval (SDNN), the standard deviation of all averaged normal sinus $\mathrm{R}-\mathrm{R}$ interval for each 5-minutes segment (SDANN), the root mean square of successive difference between normal sinus R$\mathrm{R}$ interval (RMSSD) can be calculated. (Task force of European society of cardiology, the north American society of pacing electrophysiology 1996).

\subsection{Statistical Analysis}

Was performed by using SPSS soft ware (version 12), difference among groups was analyzed by ( $\mathrm{t}$ - test) and $\mathrm{P}$ value 0.05 was considerable significant.

\section{RESUlT}

Table 1: There were no statistically significant difference between study group and control group in relation to age and gender. All subjects were detected to be in sinus rhythm without episode of sustained a trial or ventricle arrhythmia. Mean heart rate was significantly higher and mean hemoglobin, hematocrit and ferritin level were significantly lower in the study group in comparison with control group. Heart rate of study group $(116 \pm 19)$ was significantly greater than control group $(78 \pm 19)$, $\mathrm{P}<0.05, \mathrm{Hb}, \mathrm{HCT}, \mathrm{MCV}$ and ferritin value were significantly lower in study group than in control group $(8.5 \pm 2.3$ vs $13.2 \pm 0.4, \mathrm{P}<0.05$ $30.1 \pm 1.1$ vs $41.2 \pm 1.1, \mathrm{P}<0.05 \quad 67.3 \pm 2.1$ vs $84.5 \pm 2.4, \mathrm{P}<0.055 .1 \pm 0.4$ vs $97 \pm 6.5, \mathrm{P}<0.05$ respectively).

and there was no difference between male and females with regard to clinical and laboratory parameter in both groups.

Table1. Demographic and clinical characteristic of study and control group

\begin{tabular}{|l|l|l|l|}
\hline \multicolumn{1}{|c|}{ Characteristic } & \multicolumn{1}{|c|}{ Study group n(20) } & \multicolumn{1}{c|}{ Control group n(20) } & \multicolumn{1}{c|}{ P Value } \\
\hline Age(Year) & $32 \pm 6$ & $30 \pm 8$ & NS \\
\hline Male & $7(35 \%)$ & $6(30 \%)$ & $\mathrm{NS}$ \\
\hline Female & $13(65 \%)$ & $14(70 \%)$ & $\mathrm{NS}$ \\
\hline Heart Rate (bpm) & $116 \pm 19$ & $78 \pm 19$ & $<0.05$ \\
\hline Systolic blood Pressure (mmHg) & $118.6 \pm 10.4$ & $116.6 \pm 13.6$ & $\mathrm{NS}$ \\
\hline Diastolic blood pressure (mmHg) & $76.9 \pm 9.8$ & $72.8 \pm 10.6$ & $\mathrm{NS}$ \\
\hline Body mass index (kg/m $\left.{ }^{2}\right)$ & $23 \pm 2.3$ & $22.95 \pm 2.12$ & $\mathrm{NS}$ \\
\hline Random blood glucose & $93.3 \pm 17.3$ & $91.7 \pm 16.4$ & $\mathrm{NS}$ \\
\hline Hb value (g/dl) & $8.5 \pm 2.3$ & $13.2 \pm 0.4$ & $<0.05$ \\
\hline HCT value (\%) & $30.1 \pm 1.1$ & $41.2 \pm 1.1$ & $<0.05$ \\
\hline MCV (fI) & $67.3 \pm 2.1$ & $84.5 \pm 2.4$ & $<0.05$ \\
\hline Serum ferritin value (ng/ml) & $5.1 \pm 0.4$ & $97 \pm 6.5$ & $<0.05$ \\
\hline Vitamine B12 value (ng/L) & $259 \pm 65$ & $276 \pm 82$ & $\mathrm{NS}$ \\
\hline Folate (ng/ml) & $6.5 \pm 1.3$ & $\mathrm{NS}$ \\
\hline
\end{tabular}

Table 2: All time domain indices of HRV except RMSSD showed statistically significant decrease in patient compared to control group. SDNN, SDANN were significantly lower in study group than in control group $(116 \pm 38$ vs $139 \pm 41, \mathrm{P}<0.05 \quad 96 \pm 32$ vs $122 \pm 38, \mathrm{P}<0.05$ $23 \pm 12$ vs $29 \pm 11, \mathrm{P}=0.26$ respectively).

Table2. Statistical Comparison of HRV variables of study and control groups

\begin{tabular}{|l|l|l|l|}
\hline & Study group & Control group & \multicolumn{1}{c|}{ P value } \\
\hline SDNN ( m sec) & $116 \pm 38$ & $139 \pm 41$ & $<0.05$ \\
\hline SDANN ( m sec) & $96 \pm 32$ & $122 \pm 38$ & $<0.05$ \\
\hline RMSSD ( m sec) & $23 \pm 12$ & $29 \pm 11$ & $=0.26$ \\
\hline
\end{tabular}


SDNN the standard deviation of all normal sinus $\mathrm{R}-\mathrm{R}$ interval over 5 minutes; SDANN the standard deviation of all averaged normal sinus $\mathrm{R}-\mathrm{R}$ interval for each 5-minutes segment; RMSSD the root mean square of successive difference between normal sinus R-R interval.

\section{DISCUSSION}

The main finding of this study was an alteration in HRV parameters of patients with iron deficiency anemia. The imbalance between sympathetic and parasympathetic nerve activities can disturb electrophysiological properties of the heart and may probably lead to increase mortality. (Veglio F et al 1998), demonstrated diminished sympathetic activity in anemic patient with thalesemia major are indicated by lower plasma nor epinephrine level compared with control group, similar decrease in timedomain parameter of HRV was also detected in non anemic sickle cell trait carrier (Connes et al 2006) and beta thalesemia (Rutjanaprom W., et al 2009) more over both sympathetic and parasympathetic components of HRV were significantly lower in anemic patients with vitamin B12 deficiency (Sozen A, et al 1998).

(Yokusoglu M, et al 2007) detected impairment of global indices of HRV that might be caused by increased sympathetic activity and decreased parasympathetic activity in patient of iron deficiency anemia.

(Gehi A, et al 2005) proved that each $1 \mathrm{~g} / \mathrm{dl}$ decrease in hemoglobin was associated with increase odds of having low HRV. This association was still strong enough after adjustment of other factors such as left ventricle mass and ejection fraction and diastolic dysfunction.

Low HRV may actually represent the early feature of cardiac disease in thalasemic patients with no evidence of ventricle dysfunction of routine evaluation (De Chiara B, et al 2005). Based on above account anemia is associated with low HRV which put anemic patients at higher risk of sudden death especially if concomitant heart disease exists (Gehi A, et al 2005).

(Connes, et al 2006) attributed these autonomic changes to altered hemorheogi cofactor such as blood viscosity and red blood cell deformability in sickle cell trait carriers. Red cell deformability in iron deficient stat is controversial issue, while (Tillmann $\mathrm{W}$, et al 1980 and Vaya A, et al 2005) reported decreased erythrocyte deformability, some other author stating normal value (Reinhart W, 1992). Moreover iron deficiency has no effect on blood viscosity even in patients with cyanotic heart disease (Broberg C, et al 2006).

(Yokusoglu M, et al 2007 ), proposed that low oxygen tension in tissue might be the cause of altered autonomic function in iron deficiency anemia, peripheral and central chemo reflexes are the dominant autonomic mechanism regulating ventilatory patterns in response to changes in partial pressure of oxygen and carbon dioxide in arterial blood, Both reflex pathway are capable of eliciting increase in sympathetic nerve impulse and consequently may explain altered autonomic activity in patients with anemic hypoxia (Schultz HD, et al 2000).

Despite lacking adequate convincing evidence concerning exact mechanism of carotid body activation, it is assume as due either to hypoxiarelated mitochondrial respiratory chain inhibition or potassium channel suppression which lead to intracellular calcium accumulation (Lahiri, et al 2006).

\section{CONCLUSION}

Lower serum ferritin is associated with lower HRV putting anemic patient at high cardiac risk.

\section{Limitation:}

We have only been able to use the time domain parameters of HRV for technical reason. If frequency-domain parameters would have been included, the study may be more informative. However, we think that the study is still valuable because time-domain and frequencydomain parameters are related to each other. A change in one of them is generally suggestive of a change in the other (Vaishnav et al. 1994)

\section{REFERENCES}

[1] Anker,S. D, J. Comin Colet, G. Filipatos, R. Willenheimer, K Dickstein, H. Drexler, et al 2009 Ferric carboxymaltose in patients with heart failure and iron deficiency. $\mathrm{N}$. Engl. J. Med. 361:2436-2448.

[2] Aytemir K, Aksoyek S, Büyükasik Y, haznedaroglu I, Atalar E, Ozer $\mathrm{N}$, et al Assessment of autonomic nervous system functions in patients with vitamin B12 deficiency by power spectral analysis of heart rate variability. Pacing Clin Electrophysiol 2000;23;975-8.

[3] Broberg. C. S. Bax, B E Okonko D. O., Rampling, M. W., Bayne, S., Harries, C., Davidson, S. J., Uebing, A., Khan, A. A., Thein, S., Gibbs J. S., Burman, J. and 
Gatzoulis, M. A. (2006) Blood viscosity and its relationship to iron deficiency, symptoms and exercise capacity in adults with cyanotic congenital heart disease. J. Am. Coll Cardiol., 48. 356-365.

[4] Connes, P., Martin, C., Barthelemy, J. C., Monchainin, G., Atchou, G., Forsuh, A., Massarelli. R., Wouassi, D., Thiriet, P. and Pichot, V. (2006) Nocturnal autonomic nervous system activity impairment in sickle cell trait carriers. Clin Physiol Funct Imaging. 26, 87-91.

[5] De Chiara B, Crivellaro W, Sara R, Ruffini L, parolini M, Fesslova V, et al, Early detection of cardiac dysfunction in thalassemic patients by radionuclide angiography and heart rate variability analysis . Eur J haematol 2005;74:517-22.

[6] Gandhi R A, Marques JL, Selvarajah D, Emery CJ, Tesfaye S. Painful diabetic neuropathy is associated with greater autonomic dysfunction than painless diabetic neuropathy. Diabetes Care 2010;33:1585-90.

[7] Gehi A, Ix J, Shlipak M, Pipkin S, Whooly M. Relation of anemia to low heart rate variability in patients with coronary heart disease (from the heart and soul study). Am J Cardiol 2005;95:1474-7.

[8] Lahiri, S., Roy, A., Baby, S. M., Hoshi, T., Semenza, G. L. and Prabhakar, N. R. (2006) Oxygen sensing in the body. Prog. Biophys. Mol. Biol., 91, 249-286.

[9] Liew R. Prediction of sudden arrhythmic death following acute myocardial infarction. Heart 2010;96:1086-94.

[10] Reinhart, W. H. (1992) The influence of iron deficiency on erythrocyte deformability. Br. J. Haematol., 80, 550-555.

[11] Rutjanaprom W, Kanlop N, Charoenkwan P, Sittiwangkul R, Srichairatanakool S, Tantiworawit A, et al. Heart rate variability in beta thalassemia patients. Eur J Haematol 2009;83:483-9.

[12] Sangkatumvong S, Khoo MC, Coates TD. Abnormal cardiac autonomic control in sickle cell disease following transient hypoxia. Conf Proc IEEE Eng Med Biol Soc 2008;2008:1996-9.

[13] Schultz HD, Sun SY. Chemoreflex function in heart failure. Heart fail Re 2000;5:45-56.
[14] Shroeder E, Liao D, Chambless L, Prineas R, Evans G, Heiss G. Hypertension, blood pressure, and heart variability: The Atherosclerosis Risk in Communities (ARIC) study. Hypertension 2003:42;110611.

[15] Sozen A, Demirel E, Akkaya V, Kudat H, Tukek T, Yeneral $M$, et al Autonomic dysfunction in vitamin B12 deficiency: A heart rate variability study. J Auton Nery Syst 1998; 71:25-7.

[16] Task Force of the European Society of Cardiology, the North American Society of Pacing and Electrophysiology. Heart rate Variability standards of measurement, physiology interpretation and clinical use Circulation 1996;93:1043-65.

[17] Tillmann, W. and Schroter, W. (1980) Deformability of erythrocyte in iron deficiency anemia. Blut. 40, 179-186.

[18] Vaishnav, S., Stevenson, R., Marchant, B., Lagi, K., Ranjadayalan, K. and Timmis, A.D. (1994) Relation between heart rate variability early after acute myocardial infarction and long term mortality. Am J. Cardiol., 73, 653-657.

[19] Vanderlei LC, Pastre CM, Hoshi RA, Carvalho TD, Godoy MF. Basic notions of heart rate variability and its clinical applicability. Rev Bras Cir Cardiovasc 2009;24:205-17.

[20] Vaya. A., Simo, M., Santaolaria, M., Todoli, J. and Aznar, J. (2005) Red blood cell deformability in iron deficiency anemia. Clin. Hemorheol. Microcirc, 33, 75-80.

[21] Veglio F, Melchio R, Rabbia F, Molino P, Genova GC, Martini G, et al. blood pressure and heart rate in young thalassemia major patients . Am J Hypertens 1998:11:539-47.

[22] Wen T, Kwe W, Yang I, Yang T, Relationship between electrolyte and heart rate variability parameters in end stage renal failure patients before and after hemodialysis. Anatol J Cardiol 2007;7:1424.

[23] Yokusoglu M, Nevruz O, Baysan O, Uzun M, Demirkol S, Avcu F, et al. The altered autonomic system activity in iron deficiency anemia. Tohoku J Exp Med 2007: 212: 397-4

Citation: Hanan G.K. Altalhi, Asgad A. Abdalgbar. The Influence of Low Serum Ferritin on Cardiac Autonomic Regulation in Libyan Patients. ARC Journal of Nutrition and Growth. 2020; 6(1):19-22. DOI: dx.doi.org/ 10.20431/2455-2550.0601003.

Copyright: (C) 2020 Authors. This is an open-access article distributed under the terms of the Creative Commons Attribution License, which permits unrestricted use, distribution, and reproduction in any medium, provided the original author and source are credited. 